\title{
講演 7
}

\section{原発性非小細胞肺癌に対する標準的肺葉切除 術と縮小切除 佐治 久}

\section{1.はじめに}

厚生労働省がん統計によると, 肺がんの罹患数は 2008 年には 97,000 人に達し 2020 年には打よそ 12 万人に達 すると予測される.肺がん患者の約 $40 \%$ に手術適応があ ると考えられ，日本胸部外科学会の年次報告では 2012 年の本邦に打ける原発性肺癌の手術件数は 35,000 件を 超え, 罹患率の上昇とともに今後も増え続ける.

近年, 医療技術の進歩と人口動態の変化に伴い, 我々 が普段対象としている肺癌手術患者の特徵は大きく変化 している. (1)胸部 CT 検診の普及に伴う早期肺癌の増加, (2)高齢化に伴う高齢者肺癌の増加, (3)癌治療の向上に伴 う多発肺癌・多重癌の増加が挙げられる。これらは本邦 にて顕著であり，さらに，この傾向は他の先進国で今後 見られる現象であると予測する。これら最近の原発性肺 癌を対象にする場合, 根治性を担保した必要十分な標準 的縮小手術の開発・検証・EBM の確立が, 我が国の呼 吸器外科医に求められている.

新しい治療法の有効性と安全性を科学的に検証する手 法が臨床試験である．質の高い, 複数の前向き第 3 相試 験を経て有効性が証明されると, エビデンスレベルは高 くなり新治療がガイドラインで推奨される．外科治療に おけるエビデンス構築も同様であり，これからの外科医 には臨床試験を理解し遂行する能力が求められている.

第 56 回日本肺癌学会学術集会の「標準的肺葉切除と縮 小手術」の教育講演では, 標準的肺葉切除の EBM 構築の これまでの流れに加えて, 縮小切除の EBM 構築に向け て，主に本邦における流れを，各種臨床試験を解説する ことにより考察をする.

\section{2. 標準的肺葉切除}

肺癌に対する外科治療の歴史（Figure 1）は 1933 年の Grahamによる左肺全摘術の報告に端を発する. 1950 年にChurchillにより肺葉切除術が, 1960 年にCahan によりリンパ節郭清を伴う肺葉切除術が報告されて以来 約半世紀の間, 前向きの臨床試験による科学的検証はさ れてはいないものの, 肺癌に対する標準手術は肺摘除ま たは肺葉切除とされてきた。しかし，良性疾患に対して 行われてきた区域切除が 1973 年に Jensik らによって肺 癌手術に応用され, I 期肺癌に対する縮小手術の研究が 報告された.これを踏まえ, 北米を中心とした Lung Cancer Study Group により I 期肺癌に対する縮小手術の是 非を問うランダム化比較試験が計画され，その結果が 1995 年に Annals of Thoracic Surgery に Ginsberg らに よって報告された. 1

この試験は Primary endpoint を全生存期間とした肺 葉切除群と縮小切除群（区域切除または楔状切除）のラ ンダム化比較試験であり, 1982 年から 1988 年までに 276 人の臨床病期 IA 期非小細胞肺癌患者が登録された。結 果は肺葉切除群の 5 年生存割合が $63 \%$ であったのに対 して縮小切除群は $42 \%$ であり（片側 $\mathrm{p}=0.088 ）$, 縮小切 除は臨床病期 IA 期の外科治療法としてかなり劣る可能 性が示された (Figure 2)。 また, 肺葉切除群の局所再発 割合が $6 \%$ であったのに対して, 縮小切除群では約 3 倍 の $17 \%$ に局所再発が認められた $(\mathrm{p}=0.008)$. 当時, Invited commentary の Peters と Benfield による臨床試験 の質に関する批判的な意見もあったが, 臨床病期 IA 期 非小細胞肺癌に対する標準術式は肺葉切除であり, 縮小 切除は肺葉切除に耐術可能な患者には積極的に行うべき 


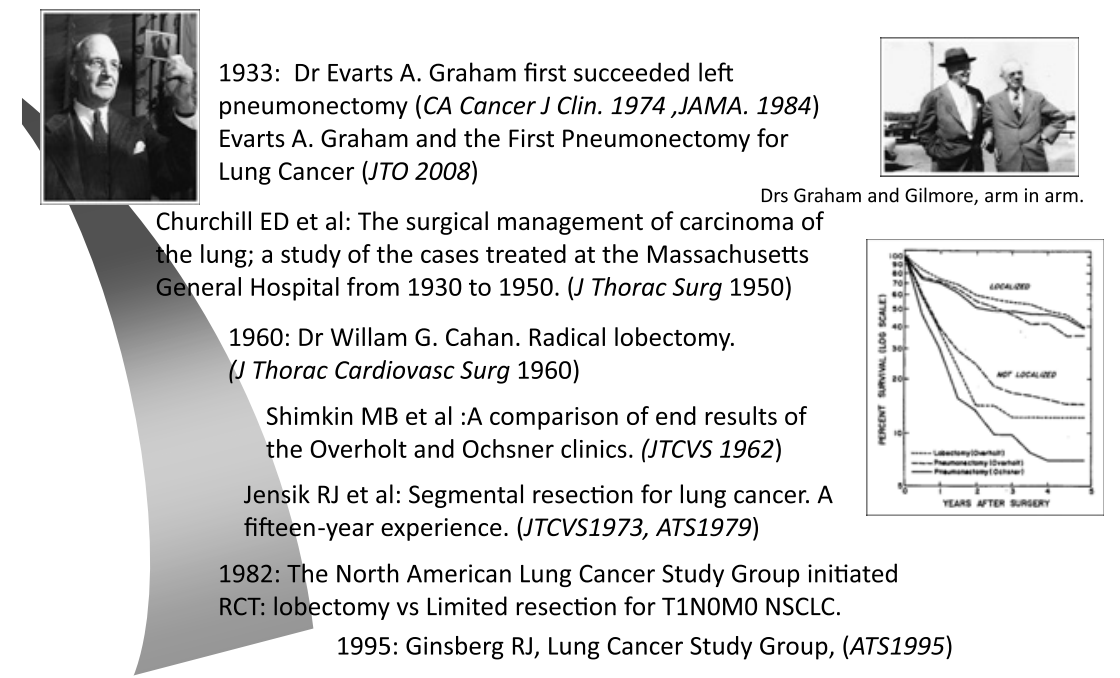

Figure 1. History of conventional lobectomy for lung cancer.
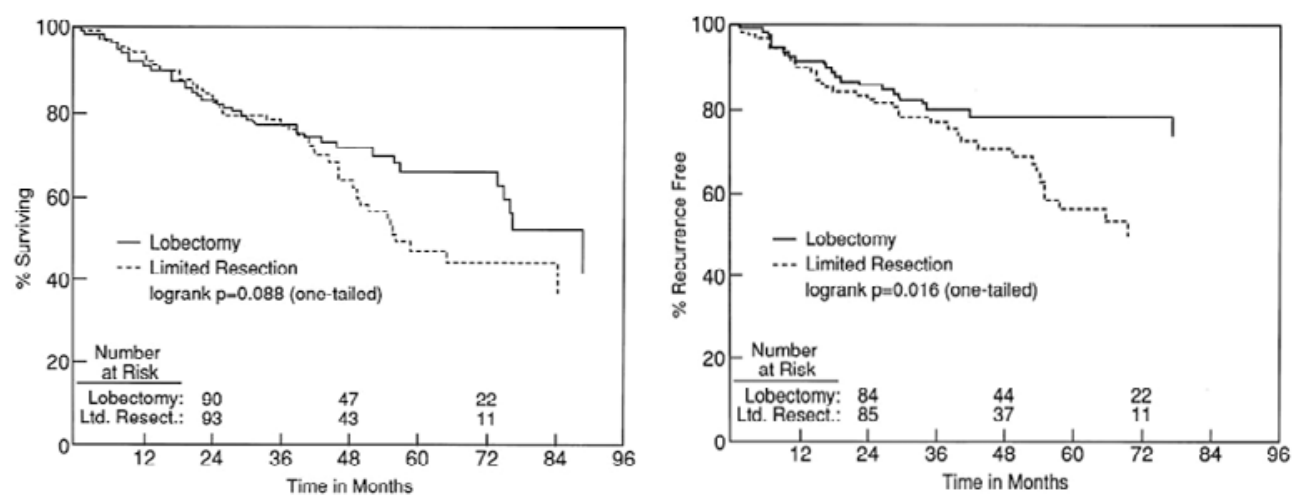

\begin{tabular}{|lcl}
\hline Locoregional Recurrence & $18 \%(21 / 122)$ & $6 \%(8 / 125)$ \\
\hline
\end{tabular}

Figure 2. Main result of randomized trial of lobectomy versus limited resection for T1N0 non-small cell lung cancer: Lung Cancer Study Group.

ではないとの見解が示された. Table 1 には早期肺癌を 対象に肺葉切除と縮小切除の有効性を比較検討した報告 をまとめたものを示す. 全体として縮小切除で十分とす る報告が多いにも関わらず，この唯一の大規模ランダム 化比較試験の結果を以って，現在も早期肺癌における標 準手術は肺葉切除とされている.

\section{3. 縮小切除術}

前章では「早期肺癌における標準手術は肺葉切除であ る」と述べるが, Table 2 に示すように, $2 \mathrm{~cm}$ 以下を対象 としたサブセット解析のある報告に限れば縮小切除を推 奨する報告が多く認められる。ささらに，現在でいう MIA （Minimary invasive adenocarcinoma）に相当する BAC
(Bronchioloalveolar Carcinoma)を対象とした場合には, 全ての報告にて縮小切除で十分であるとの見解を示して いる.これらは全て本邦からの報告であり, 胸部 CT 検診 がいち早く普及した我が国ならではの実状を反映したも のと言える. 尚, ここで一つ確認すべき点は, 縮小切除 には楔状切除と区域切除があるが，その術式には切除可 能な断端までの距離と, リンパ節郭清の有無という, 解 剖学的に大きな違いがあり, Table 4 に示すようにその 根治性には違いがあり, それぞれの対象も区別して臨床 試験の構築が必要であると考えられる. 
Table 1. Summary of Studies Comparing Sublobar Resection with Lobectomy for Early NSCLC

\begin{tabular}{|c|c|c|c|c|c|c|c|c|}
\hline \multirow[b]{2}{*}{ Year } & \multicolumn{4}{|c|}{ Pro-lobar Resection } & \multicolumn{4}{|c|}{ Pro-sublobar Resection } \\
\hline & Author & N (L vs S) & $\mathrm{T}$ & $\begin{array}{l}\text { Type of Surgery } \\
\text { Wedge (W) or } \\
\text { Segment (S) } \\
\text { Intentional (I) or } \\
\text { Compromised (C) }\end{array}$ & Author & N (L vs S) & $\mathrm{T}$ & $\begin{array}{l}\text { Type of Surgery } \\
\text { Wedge (W) or } \\
\text { Segment (S) } \\
\text { Intentional (I) or } \\
\text { Compromised (C) }\end{array}$ \\
\hline 1985 & & & & & Errett (JTCVS1985) & 97 vs 100 & $\mathrm{~T} 1+\mathrm{T} 2$ & $\mathrm{~W}(\mathrm{C})$ \\
\hline 1990 & $\begin{array}{l}\text { Warren } \\
\text { (JTCVS1994) }\end{array}$ & 105 vs 68 & $\mathrm{~T} 1+\mathrm{T} 2$ & $\mathrm{~S}$ & $\begin{array}{l}\text { Read (ATS1990) } \\
\text { Pastorino U } \\
\text { (EJSO1991) }\end{array}$ & $\begin{array}{l}131 \text { vs } 113 \\
411 \text { vs } 61\end{array}$ & $\begin{array}{l}\mathrm{T} 1 \\
\mathrm{~T} 1+\mathrm{T} 2\end{array}$ & $\begin{array}{l}W+S \\
W+S\end{array}$ \\
\hline 1995 & $\begin{array}{l}\text { LCSG } \\
\text { (ATS1995) } \\
\text { RCT } \\
\text { Martini } \\
\text { (JTCVS1995) }\end{array}$ & $\begin{array}{l}125 \text { vs } 122 \\
511 \text { vs } 62\end{array}$ & $\mathrm{~T} 1+\mathrm{T} 2$ & $\begin{array}{l}W+S(I) \\
W+S\end{array}$ & $\begin{array}{l}\text { Kodama (JTCVS1997) } \\
\text { Landreneau } \\
\text { (JTCVS1997) }\end{array}$ & $\begin{array}{l}77 \text { vs } 46 \\
117 \text { vs } 102\end{array}$ & $\begin{array}{l}\mathrm{T} 1 \\
\mathrm{~T} 1\end{array}$ & $\begin{array}{l}\mathrm{S}(\mathrm{I}) \\
\text { W (C) }\end{array}$ \\
\hline 2000 & $\begin{array}{l}\text { Miller } \\
\text { (ATS2002) }\end{array}$ & 75 vs 25 & $\mathrm{~T} 1$ & $\mathrm{~W}+\mathrm{S}$ & Miller (ATS2002) & $\begin{array}{l}139 \text { vs } 70 \\
159 \text { vs } 74 \\
121\end{array}$ & $\begin{array}{l}\mathrm{T} 1(<2 \mathrm{~cm}) \\
\mathrm{T} 1(<2 \mathrm{~cm}) \\
\mathrm{T} 1\end{array}$ & $\begin{array}{l}S(I) \\
W+S(I) \\
S(C)\end{array}$ \\
\hline 2005 & $\begin{array}{l}\text { Chang } \\
\text { (JTCVS2007) } \\
\text { Sienel } \\
\text { (EJCTS2007) } \\
\text { Kraev (Chest } \\
\text { 2007) }\end{array}$ & $\begin{array}{l}\text { SEER } \\
(10761) \\
150 \text { vs } 49 \\
215 \text { vs } 74\end{array}$ & $\begin{array}{l}\mathrm{T} 1+\mathrm{T} 2 \\
\mathrm{~T} 1 \\
\mathrm{~T} 1+\mathrm{T} 2\end{array}$ & $\begin{array}{l}W+S(C) \\
S \\
W\end{array}$ & $\begin{array}{l}\text { Martin-Ucar } \\
\text { (EJCTS2005) } \\
\text { Fernando (JTCVS2005) } \\
\text { Nakamura (BJC2005) } \\
\text { El-Sherif (ATS2006) } \\
\text { Okada (JTCVS2006) } \\
\text { Pros } \\
\text { Schuchert (ATS2007) }\end{array}$ & $\begin{array}{l}17 \text { vs } 55 \\
167 \text { vs } 124 \\
\text { Meta } \\
577 \text { vs } 207 \\
262 \text { vs } 305 \\
246 \text { vs } 182\end{array}$ & $\begin{array}{l}\mathrm{T} 1+\mathrm{T} 2 \\
\mathrm{~T} 1 \\
\mathrm{~T} 1+\mathrm{T} 2 \\
\mathrm{~T} 1+\mathrm{T} 2 \\
\mathrm{~T} 1(<2 \mathrm{~cm}) \\
\mathrm{T} 1+\mathrm{T} 2\end{array}$ & $\begin{array}{l}S(C) \\
W+S+\text { Brachy }(C) \\
W+S \\
W+S(C) \\
W+S(I) \\
S\end{array}$ \\
\hline 2010 & & & & & $\begin{array}{l}\text { Wisnivesky (Ann } \\
\text { Surg2010) }\end{array}$ & SEER (1165) & $\mathrm{T} 1(<2 \mathrm{~cm})$ & $\mathrm{W}+\mathrm{S}$ \\
\hline
\end{tabular}

R. Rami-Porta and M. Tsuboi. Eur Respir J 2009.

Justin D. Blasberg et al. JTO2010.

Matthew J. Schuchert et al. Seminars in Thoracic and Cardiovascular Surgery 2010.

Chaitan K. Narsule et al. The Cancer Journal 2011.

Table 2. Lobectomy vs Sublobar Resection for Stage I NSCLC $\leq 2 \mathrm{~cm}$

\begin{tabular}{|c|c|c|c|c|c|c|c|}
\hline \multirow{2}{*}{ Author } & \multirow{2}{*}{$\mathrm{N}$} & \multirow{2}{*}{$\mathrm{T}$} & \multirow{2}{*}{$\begin{array}{l}\text { Type of } \\
\text { Surgery }\end{array}$} & \multicolumn{2}{|c|}{$\begin{array}{l}\text { Overall 5-yr survival (\%) } \\
\text { P value }\end{array}$} & \multicolumn{2}{|c|}{$\begin{array}{l}\text { Local Recurrence Rate (\%) } \\
\text { P value }\end{array}$} \\
\hline & & & & $\begin{array}{l}<2 \mathrm{~cm} \\
\mathrm{~L} \text { vs S }\end{array}$ & $\begin{array}{l}>=2 \mathrm{~cm} \\
\text { L vs S }\end{array}$ & $\begin{array}{l}<2 \mathrm{~cm} \\
\mathrm{~L} \text { vs S }\end{array}$ & $\begin{array}{l}>=2 \mathrm{~cm} \\
\mathrm{~L} \text { vs S }\end{array}$ \\
\hline Okada (ATS2001) & 139 vs 70 & $\mathrm{~T} 1(\leq 2 \mathrm{~cm})$ & $\mathrm{S}(\mathrm{I})$ & $\begin{array}{l}77.7 \text { vs } 87.3 \\
0.1644\end{array}$ & NA & NA & NA \\
\hline $\begin{array}{l}\text { Koike (JTCVS2003) } \\
\text { Pros }\end{array}$ & 159 vs 74 & $\mathrm{~T} 1(\leq 2 \mathrm{~cm})$ & $\mathrm{W}+\mathrm{S}(\mathrm{I})$ & $\begin{array}{l}90.1 \text { vs } 89.1 \\
0.91\end{array}$ & NA & $\begin{array}{l}11.3 \text { vs } 2.7 \\
0.42\end{array}$ & NA \\
\hline Okada (JTCVS2005) & 1272 (I-III) & $\begin{array}{l}\mathrm{T} 1+2 \mathrm{~N} 0 \\
(\mathrm{n}=772)\end{array}$ & $\mathrm{W}+\mathrm{S}$ & $\begin{array}{l}92.4 \text { vs } 96.7 \text { (seg) } \\
0.9138\end{array}$ & $\begin{array}{l}2-3 \mathrm{~cm} \\
87.4 \mathrm{vs} 87.4 \text { (seg) } \\
0.9094 \\
>3 \mathrm{~cm} \\
81.3 \mathrm{vs} 62.9 \text { (seg) } \\
0.0492\end{array}$ & NA & NA \\
\hline Okada (JTCVS2006) & 205 vs 305 & $\mathrm{~T} 1(\leq 2 \mathrm{~cm})$ & $\mathrm{W}+\mathrm{S}(\mathrm{I})$ & $\begin{array}{l}83.4 \text { vs } 85.9 \\
0.2778\end{array}$ & NA & $\begin{array}{l}6.9 \text { vs } 4.9 \\
0.3524\end{array}$ & NA \\
\hline
\end{tabular}

$\mathrm{W}=$ wedge resection, $\mathrm{S}=$ segmentectomy, $\mathrm{I}=$ intentional, NA = not analysis.

\section{4. 縮小切除の EBM 構築に向けての各種臨床試験 の現状}

日本臨床腫瘍研究グループ (JCOG = Japan Clinical On- cology Group）の肺がん外科グループでは, 2002 年より 「胸部薄切 CT 所見に基づく肺野型早期肺癌の診断とそ の妥当性に関する研究 (JCOG0201)」を計画し, 病理学 的非浸潤癌を術前に正しく予測するための画像的非浸潤 
Table 3. Sublobar Resection for Bronchioloalveolar Carcnioma (BAC)

\begin{tabular}{|c|c|c|c|c|c|c|c|c|}
\hline Author & $\begin{array}{l}\text { No. fo } \\
\text { Patients }\end{array}$ & $\begin{array}{l}\text { Number of } \\
\text { GGO (\%) }\end{array}$ & $\mathrm{T}$ size & $\mathrm{N}$ status & $\begin{array}{c}\text { Type of Surgery } \\
(\mathrm{N})\end{array}$ & Histology & 5 -yr OS & $\begin{array}{c}\text { Medican Follow } \\
\text { up Time }\end{array}$ \\
\hline $\begin{array}{l}\text { Yamato } \\
\text { (ATS2001) }\end{array}$ & 42 & $42(100)$ & $=<2 \mathrm{~cm}$ & 0 & W (34), S (2), L (6) & $42 \mathrm{BAC}$ & $100 \%$ & $30 \mathrm{M}$ \\
\hline $\begin{array}{l}\text { Watanabe } \\
\text { (ATS2002) }\end{array}$ & 17 & $17(100)$ & $=<3 \mathrm{~cm}$ & 0 & W (14), S (3) & $17 \mathrm{BAC}$ & $100 \%$ & $32 \mathrm{M}$ \\
\hline $\begin{array}{l}\text { Nakata } \\
\text { (ATS2003) }\end{array}$ & 33 & $33(100)$ & $<1 \mathrm{~cm}$ & NA & W (33) & $\begin{array}{l}9 \mathrm{AAH} \\
23 \mathrm{BAC} \\
1 \mathrm{Ad}\end{array}$ & $100 \%$ & $18 \mathrm{M}$ \\
\hline $\begin{array}{l}\text { Asamura } \\
\text { (ATS2003) }\end{array}$ & 48 & $28(58)$ & $<1 \mathrm{~cm}$ & $\begin{array}{l}2 \mathrm{~N} 1 \\
1 \mathrm{~N} 2 \text { in Pt } \\
\text { with solid } \\
\text { lesion }\end{array}$ & $\begin{array}{l}W+S(15) \\
L(33)\end{array}$ & $\begin{array}{l}28 \mathrm{BAC} \\
16 \mathrm{Ad} \\
2 \mathrm{sq} \\
1 \mathrm{SCLC}\end{array}$ & $\begin{array}{l}100 \% \\
2 \text { recurrence in } \\
\text { Pt with solid } \\
\text { lesion }\end{array}$ & \\
\hline $\begin{array}{l}\text { Yamada } \\
\text { (ATS2004) }\end{array}$ & 39 & $\begin{array}{l}62 \\
\text { lesion (100) }\end{array}$ & $=<3 \mathrm{~cm}$ & 0 & W (31), S (4), L (4) & $\begin{array}{l}8 \mathrm{AAH} \\
31 \mathrm{BAC}\end{array}$ & $100 \%$ & $29.3 \mathrm{M}$ \\
\hline $\begin{array}{l}\text { Sakurai } \\
\text { (ATS2004) }\end{array}$ & 108 & ND & $=<3 \mathrm{~cm}$ & 30 in $\mathrm{Ad}$ & S (7), L (108) & $\begin{array}{l}25 \mathrm{BAC} \\
83 \mathrm{Ad}\end{array}$ & $\begin{array}{l}100 \%(\mathrm{BAC}) \\
63.5 \%(\mathrm{Ad})\end{array}$ & $61.2 \mathrm{M}$ \\
\hline $\begin{array}{l}\text { Yosida } \\
\text { (JTCVS2005) } \\
\text { (JTO2010) }\end{array}$ & 45 & $45(100)$ & $=<2 \mathrm{~cm}$ & NA & W (45) & $\begin{array}{l}5 \text { AAH } \\
2 \text { Noguchi A } \\
23 \text { Noguchi B } \\
15 \text { Noguchi C }\end{array}$ & $\begin{array}{l}100 \% \\
\frac{3 \text { cut-end }}{\text { recurrence in }} \\
\text { Noguchi B }\end{array}$ & $\begin{array}{l}50 \mathrm{M} \\
\text { More than } 5 \mathrm{yrs}\end{array}$ \\
\hline
\end{tabular}

$\mathrm{ND}=$ no data, $\mathrm{NA}=$ not analysis.

Table 4. Wedge Resection vs Segmentectomy for Stage I NSCLC

\begin{tabular}{|c|c|c|c|c|c|c|c|}
\hline \multirow{2}{*}{ Author } & \multirow{2}{*}{$\mathrm{N}$} & \multirow{2}{*}{$\mathrm{T}$} & \multirow{2}{*}{$\begin{array}{l}\text { Number of } \\
\text { Sublobar resection } \\
\text { (W vs S) }\end{array}$} & \multicolumn{2}{|c|}{ Overall 5-yr survival (\%) } & \multicolumn{2}{|c|}{ Local Recurrence Rate (\%) } \\
\hline & & & & Wedge vs Segment & $\mathrm{P}$ value & Wedge vs Segment & $P$ value \\
\hline Miller (ATS2002) & $\begin{array}{l}100 \text { (I-III) } \\
93 \text { (I) }\end{array}$ & $\mathrm{T} 1+\mathrm{T} 2$ & 13 vs 12 & 42 vs 75 & ND & 30 vs 8 & ND \\
\hline Okada (JTCVS2005) & $\begin{array}{l}1272 \text { (I-III) } \\
772 \text { (I) }\end{array}$ & $\mathrm{T} 1+\mathrm{T} 2$ & 55 vs 221 & $\begin{array}{l}96.7 \text { vs } 92.4(<2 \mathrm{~cm}) \\
39.4 \text { vs } 84.6(2-3 \mathrm{~cm}) \\
0 \text { vs } 62.9(>3 \mathrm{~cm})\end{array}$ & $\begin{array}{l}0.9163 \\
<0.0001 \\
0.0012\end{array}$ & NA & NA \\
\hline El-Sherif (ATS2006) & 81 & $\mathrm{~T} 1+\mathrm{T} 2$ & 55 vs 26 & NA & NA & 15 vs 4 & ND \\
\hline Okada (JTCVS2006) & 567 & $\mathrm{~T} 1(<2 \mathrm{~cm})$ & 60 vs 214 & 95.0 vs 93.9 & 0.4272 & NA & NA \\
\hline Sienel (EJCTS2007) & 87 & $\mathrm{~T} 1$ & 31 vs 56 & 48 vs 71 & ND & 55 vs 17 & ND \\
\hline
\end{tabular}

$\mathrm{ND}=$ no data, $\mathrm{NA}=$ not analysis.

癌の診断基準の妥当性を検討し，その結果が 2011 年に Suzuki らにより報告された. ${ }^{2}$ 計画当初の帰無仮説は否 定できなかったものの, 腫瘍径が $2 \mathrm{~cm}$ 以下かつ $\mathrm{C} / \mathrm{T}$ 比が 0.25 以下いう規準を設けて探索的に検討を行った ところ，特異度が 99.4\%（95\%CI：96.7～99.9）と極めて 高くなることが判明した.JCOG 肺がん外科グループは 西日本がん研究機構 $($ WJOG = West Japan Oncology Group）と共同で, これを画像的非浸潤癌の画像診断規準 として「胸部薄切 CT 所見に基づく肺野型早期肺癌に対 する縮小切除の第 II 相試験 (JCOG0804/WJOG4507L)」 の適格規準に含め, 2009 年より登録開始し, 2011 年 4 月には 333 例を集積し，現在最終解析結果待ちである.

さらに $2 \mathrm{~cm}$ 以下のそれ以外の画像的浸潤肺癌を対象 とした, 肺葉切除と区域切除のランダム化比較試験であ
る「肺野末梢小型非小細胞肺癌に対する肺葉切除と縮小 切除 (区域切除) の第 III 試験(JCOG0802/WJOG4607L)」 を計画・遂行した．前述した 1995 年の LCSGの試験デ ザインに似ているが, 腫瘍最大径 $2 \mathrm{~cm}$ 以下の小型肺癌 のみを対象としていること, 術式を区域切除に統一して いることが特徵であり，先の第 III 相試験の問題点が回 避されていることから区域切除の非劣性が示される可能 性は十分にあると考えている. 米国においては 2007 年に すでに「Phase III Randomized Study of Lobectomy Versus Sublobar Resection in Patients With Small Peripheral Stage IA Non-Small Cell Lung Cancer」(CALGB 140503)が開始されていたが，腫瘍最大径 $3 \mathrm{~cm}$ まで含め ていること，楔状切除も許容していること，肺結節影の 画像所見を考慮していないことが, JCOG0802/WJOG 


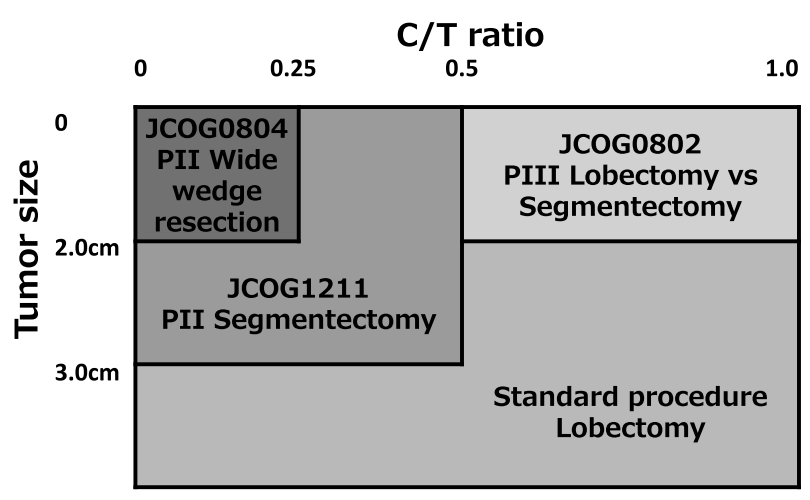

Figure 3. Future treatment strategies for small lung cancer.

4607L 異なっている. 2014 年 10 月に, 登録期間 5 年, 累 積登録数 1106 例を持ってこの大規模第 III 相試験の登 録を完了し，現在追跡調査中である。

2013 年には Asamura らにより JCOG0201 試験の長期 追跡結果が報告された. ${ }^{3}$ 先行研究で $\mathrm{C} / \mathrm{T}$ 比のカットオ フ值が 0.5 では病理学的浸潤癌を予測するための特異度 が低く，帰無仮説を否定できなかったものの，長期成績 ではすりガラス影優位な腫瘍は腫瘍最大径が $2 \mathrm{~cm}$ を超 えたとしても，予後は極めて良好であった：これをもと に腫瘍最大径 $2 \mathrm{~cm}$ 超 $3 \mathrm{~cm}$ 以下かつ $\mathrm{C} / \mathrm{T}$ 比が 0.5 以下 の腫瘍に対して，区域切除の有用性を検証する非ランダ 厶化検証的試験「胸部薄切 CT 所見に基づくすりガラス 影優位の cT1N0 肺癌に対する区域切除の非ランダム化 検証的試験 (JCOG1211)」が計画され，現在症例集積中 である. 胸部薄切 CT における肺結節の評価において C/ T 比を参考にすることについては, 様々な議論のあると
ころではあるが，本邦発のエビデンスとして世界に発信 できる歴史的な研究であり, 結果によっては肺癌外科の 歴史において約半世紀以上も変わらなかった標準治療の パラダイムシフトをもたらす可能性がある（Figure 3). 近年の多発癌や第 2 癌の増加に伴い, 今後さらに機能温 存手術の重要性が高まることが予想される。

\section{5. おわりに}

標準的肺葉切除の $\mathrm{EBM}$ 構築の流れに加えて, 縮小切 除の $\mathrm{EBM}$ 構築に向けて, 主に本邦における流れを, 各種 臨床試験を述べた. 本邦からの JCOG0802/WJOG4607L, JCOG0804/WJOG4608L, JCOG1211 の 3 つの臨床試験が 縮小手術の $\mathrm{EBM}$ を構築し，早期肺癌における標準手術 のパラダイムシフトを世界に発信する日を心待ちにして いる.

本論文内容に関連する著者の利益相反：なし

\section{REFERENCES}

1. Ginsberg RJ, Rubinstein LV. Randomized trial of lobectomy versus limited resection for T1 N0 non-small cell lung cancer. Lung Cancer Study Group. Ann Thorac Surg. 1995;60:615-622;discussion 622-623.

2. Suzuki K, Asamura H, Kusumoto M, Kondo H, Tsuchiya R. "Early" peripheral lung cancer: prognostic significance of ground glass opacity on thin-section computed tomographic scan. Ann Thorac Surg. 2002;74:1635-1639.

3. Asamura H, Hishida T, Suzuki K, Koike T, Nakamura K, Kusumoto M, et al. Radiographically determined noninvasive adenocarcinoma of the lung: survival outcomes of Japan Clinical Oncology Group 0201. J Thorac Cardiovasc Surg. 2013;146:24-30. 